\title{
Corn straw return can increase labile soil organic carbon fractions and improve water-stable aggregates in Haplic Cambisol
}

\author{
Batande Sinovuyo NDZELU, DOU Sen", ZHANG Xiaowei \\ College of Resource and Environmental Science, Jilin Agricultural University, Changchun 130118, China
}

\begin{abstract}
Corn straw return to the field is a vital agronomic practice for increasing soil organic carbon (SOC) and its labile fractions, as well as soil aggregates and organic carbon (OC) associated with water-stable aggregates (WSA). Moreover, the labile SOC fractions play an important role in OC turnover and sequestration. The aims of this study were to determine how different corn straw returning modes affect the contents of labile SOC fractions and OC associated with WSA. Corn straw was returned in the following depths: (1) on undisturbed soil surface (NTS), (2) in the 0-10 cm soil depth (MTS), (3) in the 0-20 cm soil depth (CTS), and (4) no corn straw applied (CK). After five years (2014-2018), soil was sampled in the $0-20$ and $20-40 \mathrm{~cm}$ depths to measure the water-extractable organic C (WEOC), permanganate oxidizable $\mathrm{C}\left(\mathrm{KMnO}_{4}-\mathrm{C}\right)$, light fraction organic $\mathrm{C}$ (LFOC), and WSA fractions. The results showed that compared with CK, corn straw amended soils (NTS, MTS and CTS) increased SOC content by $11.55 \%-16.58 \%$, WEOC by $41.38 \%-51.42 \%, \mathrm{KMnO}_{4}-\mathrm{C}$ and $\mathrm{LFOC}$ by $29.84 \%-34.09 \%$ and $56.68 \%-65.36 \%$ in the $0-40 \mathrm{~cm}$ soil depth. The LFOC and $\mathrm{KMnO}_{4}-\mathrm{C}$ were proved to be the most sensitive fractions to different corn straw returning modes. Compared with CK, soils amended with corn straw increased mean weight diameter by $24.24 \%-40.48 \%$ in the $0-20 \mathrm{~cm}$ soil depth. The NTS and MTS preserved more than $60.00 \%$ of OC in macro-aggregates compared with CK. No significant difference was found in corn yield across all corn straw returning modes throughout the study period, indicating that adoption of NTS and MTS would increase SOC content and improve soil structure, and would not decline crop production.
\end{abstract}

Keywords: aggregate-size distribution; corn straw return; corn yield; labile soil organic carbon fractions; Haplic Cambisol

Citation: Batande Sinovuyo NDZELU, DOU Sen, ZHANG Xiaowei. 2020. Corn straw return can increase labile soil organic carbon fractions and improve water-stable aggregates in Haplic Cambisol. Journal of Arid Land, 12(6): 1018-1030. https://doi.org/10.1007/s40333-020-0024-7

\section{Introduction}

Cultivated lands have experienced a significant decline in soil fertility, due to losses of soil organic carbon (SOC) and its labile fractions. Removal of crop residues is regarded to be the chief reason behind losses of SOC content and labile SOC fractions (Chen et al., 2017; Bongiorno et al., 2019). This practice increases direct mineralization of soil organic matter by soil microbes. In contrast, returning corn straw to the soil has been shown as alternative practices

\footnotetext{
*Corresponding author: DOU Sen (E-mail: dousen1959@126.com)

Received 2020-03-20; revised 2020-07-22; accepted 2020-08-13

(C) Xinjiang Institute of Ecology and Geography, Chinese Academy of Sciences, Science Press and Springer-Verlag GmbH Germany, part of Springer Nature 2020
} 
to reverse losses of SOC content and improve labile SOC fractions (Bongiorno et al., 2019; Mi et al., 2019). Mi et al. (2019) showed that returning crop straw into the soil improved SOC content by $28.00 \%$ in the $0-20 \mathrm{~cm}$ soil depth, compared with non-straw amended soils.

SOC is a predominant factor for improving soil fertility and plays an important role in soil function. Therefore, maintaining soil carbon (C) balance is of utmost importance for improving soil quality and $\mathrm{C}$ sequestration. Up to date, bulk SOC content is commonly used to assess the changes in soil quality. However, changes in SOC content induced by soil management practices are often difficult to detect, due to the high background values of soil C (Gregorich et al., 1994), and slow turnover rates (Yang et al., 2012). For these reasons, there is the need to evaluate reliable and sensitive indicators that may serve to assess the changes in soil quality.

A suite of labile SOC fractions, such as water extractable organic C (WEOC), hot water extractable $\mathrm{C}$ (HWC), permanganate oxidizable $\mathrm{C}\left(\mathrm{KMnO}_{4}-\mathrm{C}\right)$, microbial biomass $\mathrm{C}(\mathrm{MBC})$, particulate organic carbon (POC), and light fraction organic C (LFOC) are perceived as sensitive and good indicators of soil quality (Dikgwatlhe et al., 2014; Chen et al., 2017; Li et al., 2018; Bongiorno et al., 2019). These fractions have faster turnover rates and they respond rapidly to the changes in soil management practices. For instance, in a three-year study, Chen et al. (2017) did not observe significant changes in bulk SOC content after crop straw residues were returned, but MBC, POC, WEOC and LFOC contents were significantly increased. Therefore, assessing labile SOC fractions provide a useful index to monitor the capacity of soil to sequester $\mathrm{C}$, given that labile SOC fractions are the essential for the formation of more stable SOC. In addition to the labile SOC fractions, evaluation of carbon management index (CMI) can give the precise direction on the effects induced by soil management practices on SOC dynamics. The CMI monitors whether a soil is rehabilitating or deteriorating (Blair et al., 1994), and the increase in CMI can indicate rehabilitating soil ecosystem (Li et al., 2018; Mi et al., 2019).

The stability of soil aggregates represented by mean weight diameter (MWD), geometric mean diameter (GMD), and aggregate-size fractions are the vital indices of soil physical quality. In these attributes (MWD, GMD and aggregate-size fractions), SOC (Xue et al., 2019) and crop residues (Zhang et al., 2019) serve as major cementing agents of soil aggregates to form macro-aggregates. The macro-aggregates in turn physically protect SOC (Six et al., 2002) and labile SOC fractions (Chen et al., 2009) from rapid biochemical mineralization.

Although extensive research has been conducted on the effects of corn straw amendments on SOC, its labile fractions and aggregate-size distribution, it still remains unclear which labile SOC fraction is the most sensitive to the changes in soil management practices and can be used as a best proxy in soil quality (Bongiorno et al., 2019). Additionally, there are inconsistences regarding the most effective corn straw returning mode to build-up SOC, and which aggregate-size fraction is largely involved in the soil C preservation. Lastly, the potential contribution of building SOC as a means to increase corn production has not yet been sufficiently quantified in spite of a significant relationship between SOC and corn yield (Oldfoeld et al., 2019), and there is little consensus as to whether corn yields are maintained or yield increases or decreases after crop straw application (Song et al., 2015; Si et al., 2018; Song et al., 2019). In light to these inconsistences, a five-year (2014-2018) study was conducted in Haplic Cambisol to evaluate the effects of four different corn straw returning modes on: (1) the contents of labile SOC fractions and assessing which labile SOC fraction is the most sensitive to soil management practices; (2) water stable aggregates (WSA) and SOC distribution in aggregate-size fractions; and (3) crop yield. We expect that returning corn straw will increase the contents of labile SOC fractions and improve soil aggregation.

\section{Materials and methods}

\subsection{Study area}

The study area is located in Mount Ayliff, Eastern Cape Province of South Africa $\left(30^{\circ} 48^{\prime} 14^{\prime \prime}\right.$, 
$\left.29^{\circ} 21^{\prime} 57^{\prime \prime} \mathrm{E}\right)$. The mean altitude, temperature and precipitation of the study area are $1167.0 \mathrm{~m}$ a.s.l., $15.9^{\circ} \mathrm{C}$ and $674.0 \mathrm{~mm}$, respectively. More than $70 \%$ of precipitation occurs between November and March. Soils are classified as Haplic Cambisol in the World Reference Base classification. Soil texture is predominantly sandy clay loam. The fields were subjected to continuous corn (Zea mays L.) cropping under conventional tillage without corn straw returning since 1978, until the establishment of corn straw returning in 2014.

\subsection{Experimental design}

Corn straw was returned to the field $\left(1.4 \mathrm{hm}^{2}\right)$ under equal straw mass of $8900 \mathrm{~kg} / \mathrm{hm}^{2}$. Four treatments were randomly set with three replications. The treatments included: (1) no corn straw applied (CK), (2) corn straw placed on the undisturbed soil surface (NTS), (3) corn straw incorporated in the $0-10 \mathrm{~cm}$ soil depth (MTS), and (4) corn straw incorporated in the 0-20 cm soil depth (CTS). Under all treatments, corn straw was cut at the bottom and placed on the soil surface during harvesting, whereas it was cut at the bottom and removed from the field under CK. All plots in the fields were kept fallow for five months. During planting, soils were prepared by moldboard adjusted to till the soil in the $0-20 \mathrm{~cm}$ soil depth under CK. Under NTS treatment, a no-till planter was used on undisturbed soil surface. Under MTS treatment, corn straw was incorporated in the $0-10 \mathrm{~cm}$ soil depth with a disc plow. Under CTS treatment, corn straw was incorporated into the soil with a moldboard plow, and urea fertilizer was applied at a rate of 150 $\mathrm{kg} /\left(\mathrm{hm}^{2} \cdot \mathrm{a}\right)$ across all treatments. Corn seeds (DKC-7374, Monsanto seeds) were planted at 36,000 plant $/ \mathrm{hm}^{2}$ annually, sown in early December and harvested in late June of the following year. These management practices were repeated consecutively for five years (2014-2018).

\subsection{Soil sampling and analysis}

Random undisturbed soil samples were collected from each field in the 0-20 and 20-40 cm soil depths. After visible stones were removed, some portion of collected soil samples was broken with caution along natural break points and passed through an 8-mm sieve. The other portion was air-dried then passed through a 2-mm sieve. Soil characterization at the beginning of the experiment was not performed, due to the long history of conventional production on the fields (>40 a). Sun et al. (2012) reported that conventionally tilled fields approach equilibrium in terms of C inputs-outputs after 30-50 a. Therefore, the fields in the present study were considered adequate beginning conditions for the current experimental objectives.

\subsubsection{Soil property}

Soil $\mathrm{pH}$ and electrical conductivity (EC) were determined in a soil-water suspension of 1.0:2.5 ratio. Available phosphorus $(\mathrm{P})$ and potassium $(\mathrm{K})$ were extracted by Bray II and ammonium acetate methods, respectively. Available nitrogen (N) was extracted by $2 \mathrm{~mol} / \mathrm{L} \mathrm{KCl}$ following the method described in details by Okalebo et al. (2002). Total nitrogen (TN) was determined by Kjeldahl method (Bremner et al., 1982). SOC content was determined by wet modified-oxidation method, by treating $0.2 \mathrm{~g}$ of soil with $\mathrm{K}_{2} \mathrm{Cr}_{2} \mathrm{O}_{7}-\mathrm{H}_{2} \mathrm{SO}_{4}$ (Zhang et al., 2020). Soil bulk density was measured by core method (Okalebo et al., 2002).

\subsubsection{Labile soil organic carbon fractions}

The $\mathrm{KMnO}_{4}-\mathrm{C}$ fraction was determined in $2.5 \mathrm{~g}$ of soil by distilled water and $0.2 \mathrm{~mol} / \mathrm{L}$ potassium permanganate oxidation method (Culman et al., 2012). The absorbance of soil solution was measured at $550 \mathrm{~nm}$.

WEOC and HWC were sequentially extracted from $5 \mathrm{~g}$ of air-dried soil in a soil-water suspension of 1.0:6.0 ratio at $25^{\circ} \mathrm{C}$ and $70^{\circ} \mathrm{C}$, respectively (Changtingny et al., 2010). After filtering, HWC and WEOC solutions were measured with a TOC (total organic carbon) analyser (Shimadzu TOC-Vcph, Japan).

MBC was estimated from the increase in organic $\mathrm{C}$ in the $0.5 \mathrm{~mol} / \mathrm{L}$ potassium sulphate $\left(\mathrm{K}_{2} \mathrm{SO}_{4}\right)$ extracts of fumigated soils (Vance et al., 1987). $\mathrm{MBC}$ in $\mathrm{K}_{2} \mathrm{SO}_{4}$ extract was determined by a TOC analyser (Shimadzu TOC-Vcph, Japan).

Particulate organic C (POC) was determined following the method by Cambardella and Elliott (1992). Briefly, $50 \mathrm{~g}$ of air-dried soil was treated with sodium hexametaphosphate under 
permanent shaking for $16 \mathrm{~h}$. The soil solution was thoroughly rinsed with distilled water passed through a $53-\mu \mathrm{m}$ sieve and soil material retained by a sieve was designated as POC.

We separated the LFOC by density fraction method described in Yang et al. (2012) using sodium iodide (NaI) solution with a density of $1.70 \mathrm{~g} / \mathrm{cm}^{3}$. Exactly $30 \mathrm{~g}$ of soil was treated with NaI solution. The contents were shaken for $1 \mathrm{~h}$ on a horizontal shaker (300 rpm) and the suspension was centrifuged for $30 \mathrm{~min}$, thereafter light floating materials were filtered through a glass fibre filter and designated as LFOC. This process was repeated three times and LFOC was thoroughly rinsed with distilled water. The recovered LFOC and POC fractions were oven dried at $60^{\circ} \mathrm{C}$ for $48 \mathrm{~h}$ and analysed for SOC content.

\subsubsection{Aggregate-size distribution}

Aggregate-size fractions of soil passed through an 8-mm sieve were measured with a modified wet-sieving procedure (Elliott, 1986) by weighing $100 \mathrm{~g}$ of soil. The soil was nested onto a series of sieves and processed with TMC-100 Soil Aggregate Analyzer (Huafeng Company, China). This wet-sieving procedure resulted into four aggregate-size fractions: (1) large macro-aggregates (>2.000 mm), (2) small macro-aggregates (2.000-0.250 mm), (3) micro-aggregates $(0.250-0.053$ $\mathrm{mm})$, and (4) silt/clay fraction $(<0.053 \mathrm{~mm})$. All fractions were oven dried at $60^{\circ} \mathrm{C}$ for determining SOC content.

\subsection{Corn yield}

Corn yield was estimated in late July every year by manually harvesting corn. Grain samples were air-dried on the ground by threshing, until reaching a uniform moisture level of about $14 \%$ water content and then weighed (Song et al., 2015; Si et al., 2018).

\subsection{Calculation and statistical analysis}

We calculated CMI according to the method of Blair et al. (1994):

$\mathrm{CMI}=$ Carbon pool index $(\mathrm{CPI}) \times$ Lability index $(\mathrm{LI}) \times 100$,

$$
\mathrm{CPI}=\frac{\text { Organic } \mathrm{C} \text { content of soil sample }}{\text { Organic } \mathrm{C} \text { content of referenced soil sample }} \text {, }
$$

$$
\mathrm{LI}=\frac{\text { Lability of } \mathrm{C} \text { in soil sample }}{\text { Lability of } \mathrm{C} \text { in referenced soil sample }} \text {, }
$$

$$
\text { Lability of } \mathrm{C}=\frac{\mathrm{KMnO}_{4}-\mathrm{C}}{\mathrm{TOC}-\mathrm{KMnO}_{4}-\mathrm{C}} .
$$

Sensitivity index (SI, \%) was computed using the following equation (Benbi et al., 2015):

$$
\mathrm{SI}=\frac{\mathrm{C} \text { fraction in soil in a given treatment }-\mathrm{C} \text { fraction in referenced soil }}{\mathrm{C} \text { fraction in referenced soil }} \times 100 \% \text {. }
$$

Water stable aggregates (WSA, \%) on each aggregate-size fraction were calculated using the following equation:

$$
\text { WSA }=\frac{\text { Weight of aggregate-size fractions }- \text { Weight of sand fraction }}{\text { Total weight }- \text { Weight of sand fraction }} \times 100 \% \text {. }
$$

MWD (mm) and geometric mean diameter (GMD, mm) of WSA were calculated using the following formula of Kemper and Rosenau (1986):

$$
\begin{gathered}
\text { MWD }=\sum_{i=1}^{n} x_{i} \times w_{i}, \\
\operatorname{GWD}=\exp \left(\frac{\sum_{i=1}^{n} w_{i} \log x_{i}}{\sum_{i=1}^{n} w_{i}}\right),
\end{gathered}
$$

where $x_{i}$ is the mean diameter of aggregate fraction $i(\mathrm{~mm})$; and $w_{i}$ is the mass proportion of aggregate fraction. 
We calculated organic carbon preservation capacity (CPC, g/kg) of the soil aggregates according to Song et al. (2019):

$$
\mathrm{CPC}=\frac{\mathrm{MAC}_{i} \times \mathrm{MA}_{i}}{100},
$$

where $\mathrm{MAC}_{i}$ is the organic carbon content associated with each soil aggregate-size fraction $(\mathrm{g} / \mathrm{kg})$; and $\mathrm{MA}_{i}$ is the aggregate-size distribution (\%) of a given fraction $(>2.000,2.000-0.250$, $0.250-0.053$ and $<0.053 \mathrm{~mm}$ ).

Analysis of variance was conducted to compare the effects of different corn straw returning modes on SOC, labile SOC fractions and aggregate-size fractions using SPSS software (IBM Statistics 21.0, IBM Corp., Armonk, USA). Significance differences among treatment means were evaluated using the least significant difference test at $P<0.05$ level. Correlations were evaluated with Pearson's correlation coefficients $(r)$ across all corn straw returning modes.

\section{Results}

\subsection{Soil property}

Soil organic C, TN, available P and K contents were $14.21-17.92$ g/kg, 0.14\%-0.27\%, 159-179 $\mathrm{mg} / \mathrm{kg}$ and $22.70-30.72 \mathrm{mg} / \mathrm{kg}$, respectively (Table 1). The contents of these soil parameters were significantly higher in soils amended with corn straw, and the order of them was as follows: NTS $>$ MTS $>$ CTS $>$ CK in the $0-20 \mathrm{~cm}$ and CTS $>$ MTS $>$ CK $>$ NTS in the 20-40 $\mathrm{cm}$ soil depth. Meanwhile, soil $\mathrm{pH}, \mathrm{EC}, \mathrm{C} / \mathrm{N}$ ratio, available $\mathrm{N}$ and bulk density were not significantly different in corn straw amended soils in the $0-20 \mathrm{~cm}$ soil depth, and these parameters decreased with an increase in soil depth (Table 1).

Table 1 Soil properties under different corn straw returning modes in the 0-20 and 20-40 cm soil depths

\begin{tabular}{|c|c|c|c|c|c|}
\hline $\begin{array}{l}\text { Soil depth } \\
\quad(\mathrm{cm})\end{array}$ & Parameter & NTS & MTS & CTS & CK \\
\hline \multirow[t]{8}{*}{$0-20$} & $\mathrm{pH}$ & $5.10 \pm 0.09^{\mathrm{a}}$ & $5.15 \pm 0.14^{\mathrm{a}}$ & $5.21 \pm 0.11^{\mathrm{a}}$ & $5.17 \pm 0.12^{\mathrm{a}}$ \\
\hline & $\mathrm{EC}(\mu \mathrm{S} / \mathrm{cm})$ & $73.70 \pm 0.81^{\mathrm{a}}$ & $70.83 \pm 0.33^{\mathrm{a}}$ & $61.68 \pm 1.02^{\mathrm{b}}$ & $72.09 \pm 0.58^{\mathrm{a}}$ \\
\hline & SOC (g/kg) & $17.92 \pm 1.10^{\mathrm{a}}$ & $15.89 \pm 0.68^{\mathrm{b}}$ & $15.65 \pm 0.90^{\mathrm{b}}$ & $14.21 \pm 0.59^{c}$ \\
\hline & TN (\%) & $0.27 \pm 0.05^{\mathrm{a}}$ & $0.23 \pm 0.07^{\mathrm{a}}$ & $0.26 \pm 0.04^{\mathrm{a}}$ & $0.12 \pm 0.01^{\mathrm{b}}$ \\
\hline & N (mg/kg) & $151.31 \pm 19.20^{\mathrm{a}}$ & $142.63 \pm 17.01^{\mathrm{a}}$ & $116.72 \pm 11.61^{\mathrm{b}}$ & $105.03 \pm 12.89^{b}$ \\
\hline & $\mathrm{P}(\mathrm{mg} / \mathrm{kg})$ & $25.75 \pm 1.01^{\mathrm{a}}$ & $23.42 \pm 1.63^{\mathrm{a}}$ & $19.66 \pm 1.65^{\mathrm{b}}$ & $17.01 \pm 1.12^{\mathrm{c}}$ \\
\hline & $\mathrm{K}(\mathrm{mg} / \mathrm{kg})$ & $179.29 \pm 9.42^{\mathrm{a}}$ & $169.33 \pm 6.18^{\mathrm{a}}$ & $155.83 \pm 7.42^{\mathrm{b}}$ & $131.09 \pm 9.92^{\mathrm{c}}$ \\
\hline & Bulk density $\left(\mathrm{g} / \mathrm{cm}^{3}\right)$ & $1.39 \pm 0.07^{\mathrm{a}}$ & $1.43 \pm 0.08^{\mathrm{a}}$ & $1.42 \pm 0.09^{\mathrm{a}}$ & $1.48 \pm 0.05^{\mathrm{a}}$ \\
\hline \multirow[t]{8}{*}{$20-40$} & $\mathrm{pH}$ & $5.13 \pm 0.04^{\mathrm{a}}$ & $5.23 \pm 0.11^{\mathrm{a}}$ & $5.49 \pm 0.35^{\mathrm{a}}$ & $5.17 \pm 0.02^{\mathrm{a}}$ \\
\hline & $\mathrm{EC}(\mu \mathrm{S} / \mathrm{cm})$ & $68.29 \pm 1.76^{\mathrm{a}}$ & $69.91 \pm 1.92^{\mathrm{a}}$ & $59.42 \pm 1.43^{\mathrm{b}}$ & $70.83 \pm 1.74^{\mathrm{a}}$ \\
\hline & SOC (g/kg) & $13.75 \pm 0.63^{b}$ & $13.98 \pm 0.58^{\mathrm{b}}$ & $14.82 \pm 0.71^{\mathrm{a}}$ & $12.21 \pm 0.80^{\mathrm{c}}$ \\
\hline & TN (\%) & $0.13 \pm 0.00^{\mathrm{b}}$ & $0.15 \pm 0.02^{b}$ & $0.21 \pm 0.02^{\mathrm{a}}$ & $0.14 \pm 0.01^{b}$ \\
\hline & $\mathrm{N}(\mathrm{mg} / \mathrm{kg})$ & $93.16 \pm 9.01^{\mathrm{ab}}$ & $95.76 \pm 7.12^{\mathrm{ab}}$ & $109.17 \pm 8.66^{\mathrm{a}}$ & $90.35 \pm 6.64^{\mathrm{b}}$ \\
\hline & $\mathrm{P}(\mathrm{mg} / \mathrm{kg})$ & $12.23 \pm 0.79^{c}$ & $15.10 \pm 0.46^{\mathrm{b}}$ & $17.10 \pm 0.13^{\mathrm{a}}$ & $11.92 \pm 0.29^{c}$ \\
\hline & $\mathrm{K}(\mathrm{mg} / \mathrm{kg})$ & $95.21 \pm 4.65^{\mathrm{b}}$ & $110.12 \pm 8.26^{\mathrm{a}}$ & $122.08 \pm 5.91^{\mathrm{a}}$ & $97.15 \pm 3.79^{\mathrm{b}}$ \\
\hline & Bulk density $\left(\mathrm{g} / \mathrm{cm}^{3}\right)$ & $1.41 \pm 0.03^{\mathrm{a}}$ & $1.48 \pm 0.05^{\mathrm{a}}$ & $1.44 \pm 0.04^{\mathrm{a}}$ & $1.51 \pm 0.12^{\mathrm{a}}$ \\
\hline
\end{tabular}

Note: EC, electric conductivity; SOC, soil organic carbon; TN, total nitrogen; N, available nitrogen; P, available phosphorus; K, available potassium; NTS, corn straw placed on undisturbed soil surface; MTS, corn straw incorporated in the $0-10 \mathrm{~cm}$ soil depth; CTS, corn straw incorporated in the $0-20 \mathrm{~cm}$ soil depth; CK, no corn straw returned; Mean \pm SE. Different lowercase letters within the same row indicate significant differences among different corn straw returning modes at $P<0.05$ level. Abbreviations are the same in Tables 2-6. 


\subsection{Concentration of labile SOC fraction}

Across all corn straw returning modes, the contents of WEOC, $\mathrm{HWC}, \mathrm{KMnO}_{4}-\mathrm{C}, \mathrm{MBC}$ and LFOC increased in the order of NTS $>$ MTS $>$ CTS $>$ CK in the $0-20 \mathrm{~cm}$, and CTS $>$ MTS $>$ CK $>$ NTS in the 20-40 cm soil depth (Table 2). Compared with CK, corn straw amended soils increased WEOC content by $41.38 \%-1.42 \%, \mathrm{KMnO}_{4}$-C by $29.84 \%-33.09 \%$ and $\mathrm{LFOC}$ by $56.68 \%-65.36 \%$ in the $0-40 \mathrm{~cm}$ soil depth. WEOC fraction represented the lowest percentage to SOC $(0.48 \%-1.52 \%)$; meanwhile, POC represented the highest percentage to SOC $(7.70 \%-14.62 \%)$ in the $0-40 \mathrm{~cm}$ soil depth (Table 2).

Table 2 Effects of different corn straw returning modes on labile SOC fractions and their contributions to SOC in the $0-20$ and $20-40 \mathrm{~cm}$ soil depths

\begin{tabular}{|c|c|c|c|c|c|}
\hline $\begin{array}{c}\text { Soil depth } \\
(\mathrm{cm})\end{array}$ & Parameter & NTS & MTS & CTS & CK \\
\hline \multirow[t]{12}{*}{$0-20$} & WEOC (g/kg) & $0.28 \pm 0.04^{\mathrm{a}}$ & $0.18 \pm 0.03^{\mathrm{b}}$ & $0.08 \pm 0.04^{c}$ & $0.07 \pm 0.01^{\mathrm{c}}$ \\
\hline & Percentage of WEOC (\%) & $1.56 \pm 0.05^{\mathrm{a}}$ & $1.13 \pm 0.03^{\mathrm{b}}$ & $0.51 \pm 0.02^{\mathrm{c}}$ & $0.48 \pm 0.05^{c}$ \\
\hline & HWC (g/kg) & $0.41 \pm 0.01^{\mathrm{a}}$ & $0.33 \pm 0.04^{\mathrm{b}}$ & $0.17 \pm 0.01^{\mathrm{c}}$ & $0.16 \pm 0.01^{\mathrm{c}}$ \\
\hline & Percentage of HWC (\%) & $2.29 \pm 0.08^{\mathrm{a}}$ & $2.07 \pm 0.04^{\mathrm{b}}$ & $1.09 \pm 0.02^{\mathrm{c}}$ & $1.13 \pm 0.09^{c}$ \\
\hline & $\mathrm{KMnO}_{4}-\mathrm{C}(\mathrm{g} / \mathrm{kg})$ & $0.87 \pm 0.02^{\mathrm{a}}$ & $0.72 \pm 0.09^{\mathrm{ab}}$ & $0.60 \pm 0.10^{\mathrm{b}}$ & $0.31 \pm 0.02^{\mathrm{c}}$ \\
\hline & Percentage of $\mathrm{KMnO}_{4}-\mathrm{C}(\%)$ & $4.86 \pm 0.14^{\mathrm{a}}$ & $4.53 \pm 0.10^{\mathrm{a}}$ & $3.85 \pm 0.09^{\mathrm{b}}$ & $2.18 \pm 0.05^{c}$ \\
\hline & $\operatorname{MBC}(\mathrm{g} / \mathrm{kg})$ & $0.55 \pm 0.05^{\mathrm{a}}$ & $0.41 \pm 0.01^{\mathrm{b}}$ & $0.30 \pm 0.03^{c}$ & $0.28 \pm 0.03^{c}$ \\
\hline & Percentage of MBC (\%) & $3.07 \pm 0.05^{\mathrm{a}}$ & $2.58 \pm 0.07^{\mathrm{b}}$ & $1.92 \pm 0.03^{c}$ & $1.96 \pm 0.08^{\mathrm{c}}$ \\
\hline & LFOC (g/kg) & $2.07 \pm 0.07^{\mathrm{a}}$ & $1.84 \pm 0.06^{\mathrm{b}}$ & $1.80 \pm 0.10^{\mathrm{b}}$ & $0.54 \pm 0.05^{c}$ \\
\hline & Percentage of LFOC (\%) & $11.55 \pm 0.21^{\mathrm{a}}$ & $11.58 \pm 0.19^{\mathrm{a}}$ & $11.50 \pm 0.28^{\mathrm{a}}$ & $3.80 \pm 0.24^{\mathrm{b}}$ \\
\hline & POC $(g / k g)$ & $2.62 \pm 0.10^{\mathrm{a}}$ & $2.24 \pm 0.09^{\mathrm{b}}$ & $2.09 \pm 0.08^{c}$ & $1.47 \pm 0.07^{\mathrm{d}}$ \\
\hline & Percentage of POC (\%) & $14.62 \pm 1.43^{\mathrm{a}}$ & $14.10 \pm 1.22^{\mathrm{a}}$ & $13.35 \pm 1.16^{\mathrm{a}}$ & $10.34 \pm 0.87^{b}$ \\
\hline \multirow[t]{12}{*}{$20-40$} & WEOC (g/kg) & $0.07 \pm 0.01^{\mathrm{c}}$ & $0.11 \pm 0.02^{\mathrm{b}}$ & $0.21 \pm 0.03^{\mathrm{a}}$ & $0.10 \pm 0.02^{\mathrm{b}}$ \\
\hline & Percentage of WEOC (\%) & $0.73 \pm 0.05^{c}$ & $0.96 \pm 0.02^{\mathrm{b}}$ & $1.42 \pm 0.11^{\mathrm{a}}$ & $0.58 \pm 0.03^{\mathrm{d}}$ \\
\hline & HWC (g/kg) & $0.18 \pm 0.05^{c}$ & $0.21 \pm 0.03^{b}$ & $0.38 \pm 0.02^{\mathrm{a}}$ & $0.13 \pm 0.01^{\mathrm{c}}$ \\
\hline & Percentage of HWC (\%) & $1.31 \pm 0.02^{\mathrm{b}}$ & $1.32 \pm 0.05^{\mathrm{b}}$ & $2.56 \pm 0.12^{\mathrm{a}}$ & $1.07 \pm 0.08^{c}$ \\
\hline & $\mathrm{KMnO}_{4}-\mathrm{C}(\mathrm{g} / \mathrm{kg})$ & $0.45 \pm 0.02^{c}$ & $0.52 \pm 0.04^{\mathrm{b}}$ & $0.64 \pm 0.01^{\mathrm{a}}$ & $0.56 \pm 0.01^{\mathrm{b}}$ \\
\hline & Percentage of $\mathrm{KMnO}_{4}-\mathrm{C}(\%)$ & $3.27 \pm 0.09^{c}$ & $3.27 \pm 0.08^{\mathrm{c}}$ & $4.32 \pm 0.04^{\mathrm{a}}$ & $3.96 \pm 0.07^{\mathrm{b}}$ \\
\hline & $\operatorname{MBC}(\mathrm{g} / \mathrm{kg})$ & $0.20 \pm 0.02^{\mathrm{c}}$ & $0.31 \pm 0.06^{\mathrm{a}}$ & $0.36 \pm 0.02^{\mathrm{a}}$ & $0.28 \pm 0.03^{\mathrm{b}}$ \\
\hline & Percentage of MBC (\%) & $1.45 \pm 0.02^{\mathrm{c}}$ & $1.95 \pm 0.05^{\mathrm{b}}$ & $2.43 \pm 0.05^{\mathrm{a}}$ & $2.45 \pm 0.09^{\mathrm{a}}$ \\
\hline & LFOC (g/kg) & $1.29 \pm 0.03^{b}$ & $1.23 \pm 0.09^{\mathrm{b}}$ & $2.04 \pm 0.05^{\mathrm{a}}$ & $0.79 \pm 0.03^{c}$ \\
\hline & Percentage of LFOC (\%) & $9.38 \pm 0.11^{\mathrm{b}}$ & $8.80 \pm 0.09^{\mathrm{c}}$ & $13.77 \pm 0.19^{\mathrm{a}}$ & $6.47 \pm 0.10^{\mathrm{d}}$ \\
\hline & POC $(g / k g)$ & $1.39 \pm 0.04^{\mathrm{c}}$ & $1.55 \pm 0.09^{b}$ & $1.93 \pm 0.02^{\mathrm{a}}$ & $0.94 \pm 0.03^{\mathrm{d}}$ \\
\hline & Percentage of POC (\%) & $10.11 \pm 0.06^{\mathrm{b}}$ & $11.09 \pm 0.08^{\mathrm{b}}$ & $13.02 \pm 0.09^{\mathrm{a}}$ & $7.70 \pm 0.03^{c}$ \\
\hline
\end{tabular}

Note: WEOC, water extractable organic carbon; HWC, hot water extractable carbon; $\mathrm{KMnO}_{4}-\mathrm{C}$, permanganate oxidizable carbon; MBC, microbial biomass carbon; LFOC, light fraction organic carbon; POC, particulate organic carbon. Mean \pm SE. Different lowercase letters within the same row indicate significant differences among different corn straw returning modes at $P<0.05$ level. Abbreviations are the same as in Tables 3-6.

\subsection{Sensitivity index of labile SOC fraction and its relationship with SOC content}

Sensitivity index of WEOC varied from 58\% to 300\%, HWC from 6\% to $156 \%$, $\mathrm{KMnO}_{4}-\mathrm{C}$ from $94 \%$ to $181 \%$, MBC from $7 \%$ to $96 \%$, LFOC from $233 \%$ to $942 \%$, and POC from $34 \%$ to $69 \%$ across all corn straw returning modes in the $0-40 \mathrm{~cm}$ soil depth (Table 3).

WEOC, LFOC and $\mathrm{KMnO}_{4}-\mathrm{C}$ proved to be the most sensitive fractions to different corn straw returning modes. The six labile SOC fractions were highly and positively correlated with SOC and with each other (Table 4). Furthermore, $\mathrm{KMnO}_{4}-\mathrm{C}(r=0.950, P=0.05)$ and LFOC $(r=0.966$, $P<0.05$ ) showed positive and significant associations with SOC (Table 4). 
Table 3 Sensitivity indices of SOC and labile SOC fractions under different corn straw returning modes in the 0-40 cm soil depth

\begin{tabular}{cccccccc}
\hline \multirow{2}{*}{ Treatment } & \multicolumn{9}{c}{ Sensitivity index (\%) } \\
\cline { 2 - 7 } & SOC & WEOC & HWC & KMnO $_{4}$-C & MBC & LFOC & POC \\
\hline NTS & 25 & 300 & 156 & 181 & 96 & 533 & 69 \\
MTS & 12 & 157 & 106 & 132 & 46 & 241 & 32 \\
CTS & 9 & 58 & 6 & 94 & 7 & 233 & 34 \\
\hline
\end{tabular}

Table 4 Pearson's correlation coefficients $(r)$ between SOC and labile SOC fractions under different corn straw returning modes in the $0-40 \mathrm{~cm}$ soil depth

\begin{tabular}{|c|c|c|c|c|c|c|}
\hline & SOC & WEOC & HWC & $\mathrm{KMnO}_{4}-\mathrm{C}$ & MBC & LFOC \\
\hline WEOC & 0.917 & & & & & \\
\hline HWC & 0.874 & $0.987^{*}$ & & & & \\
\hline $\mathrm{KMnO}_{4}-\mathrm{C}$ & $0.950^{*}$ & 0.880 & 0.882 & & & \\
\hline MBC & 0.934 & $0.998^{* *}$ & $0.977^{*}$ & 0.884 & & \\
\hline LFOC & $0.966^{*}$ & 0.692 & 0.692 & 0.948 & 0.691 & \\
\hline POC & 0.851 & 0.859 & 0.859 & $0.996^{* *}$ & 0.878 & $0.951^{*}$ \\
\hline
\end{tabular}

Note: ${ }^{*}$ and ${ }^{* *}$ mean significant correlations at $P<0.05$ and $P<0.01$ levels (2-tailed), respectively.

\subsection{Carbon pool index (CPI), lability index (LI), and carbon management index (CMI)}

CMI values ranged from 79.26 to 288.19 across all corn straw returning modes in their corresponding depth (Table 5). The highest values of CPI and CMI in the $0-20 \mathrm{~cm}$ soil depth occurred under NTS. In the $20-40 \mathrm{~cm}$ soil depth, it was CTS that produced the highest values of CMI and LI (Table 5).

Table 5 Carbon pool index (CPI), lability index (LI), and carbon management index (CMI) under different corn straw returning modes in the $0-20$ and $20-40 \mathrm{~cm}$ soil depths

\begin{tabular}{cccccc}
\hline Soil depth $(\mathrm{cm})$ & Parameter & NTS & MTS & CTS & CK \\
\hline $0-20$ & CPI & $1.26 \pm 0.09^{\mathrm{a}}$ & $1.12 \pm 0.06^{\mathrm{b}}$ & $1.10 \pm 0.05^{\mathrm{b}}$ & $1.00 \pm 0.00^{\mathrm{c}}$ \\
& LI & $2.29 \pm 0.12^{\mathrm{a}}$ & $2.13 \pm 0.08^{\mathrm{a}}$ & $2.29 \pm 0.11^{\mathrm{a}}$ & $1.00 \pm 0.00^{\mathrm{b}}$ \\
& CMI & $288.19 \pm 2.34^{\mathrm{a}}$ & $237.94 \pm 1.98^{\mathrm{c}}$ & $252.03 \pm 2.65^{\mathrm{b}}$ & $100.00 \pm 0.00^{\mathrm{d}}$ \\
\multirow{2}{*}{$20-40$} & CPI & $1.13 \pm 0.03^{\mathrm{b}}$ & $1.14 \pm 0.09^{\mathrm{b}}$ & $1.27 \pm 0.00^{\mathrm{a}}$ & $1.00 \pm 0.00^{\mathrm{c}}$ \\
& LI & $0.70 \pm 0.08^{\mathrm{c}}$ & $0.80 \pm 0.05^{\mathrm{bc}}$ & $0.94 \pm 0.04^{\mathrm{b}}$ & $1.00 \pm 0.00^{\mathrm{a}}$ \\
& CMI & $79.26 \pm 1.93^{\mathrm{d}}$ & $92.02 \pm 1.12^{\mathrm{c}}$ & $113.97 \pm 2.46^{\mathrm{a}}$ & $100.00 \pm 0.00^{\mathrm{b}}$ \\
\hline
\end{tabular}

Note: Different lowercase letters within the same row indicate significant differences among different corn straw returning modes at $P<0.05$ level. Mean \pm SE.

\subsection{Aggregate stability and aggregate-size distribution}

Corn straw returning modes significantly $(P<0.05)$ affected soil MWD, GMD and $>2.000 \mathrm{~mm}$ aggregate-size fraction in the $0-20 \mathrm{~cm}$ soil depth, but seldom in the $20-40 \mathrm{~cm}$ depth (Fig. 1). These parameters were positively correlated with SOC in the $0-40 \mathrm{~cm}$ soil depth (Table 6).

The macro-aggregates $(>0.250 \mathrm{~mm})$ accounted for more than $75 \%$ of total soil weight in soils amended with corn straw, whereas that of CK accounted for less than $60 \%$ of total soil weight in both soil depths. Irrespective of corn straw returning modes, the distribution of $<0.053 \mathrm{~mm}$ fraction accounted for less than $10 \%$ of total soil weight in both soil depths (Fig. 1).

\subsection{SOC and CPC associated with soil aggregates}

Among all WSA size fractions, the highest SOC content was measured in $>0.250 \mathrm{~mm}$ aggregate fraction, which accounted for $61.85 \%-72.10 \%$ of SOC across all corn straw returning modes and soil depths (Fig. 2). The SOC associated with soil aggregates appeared to decline with decreasing aggregate-size fractions. Compared with CK, SOC associated with $>2.000 \mathrm{~mm}$ aggregate fraction increased by $11.13 \%$ under CTS, by $10.81 \%$ under MTS and by $16.93 \%$ under NTS in the 

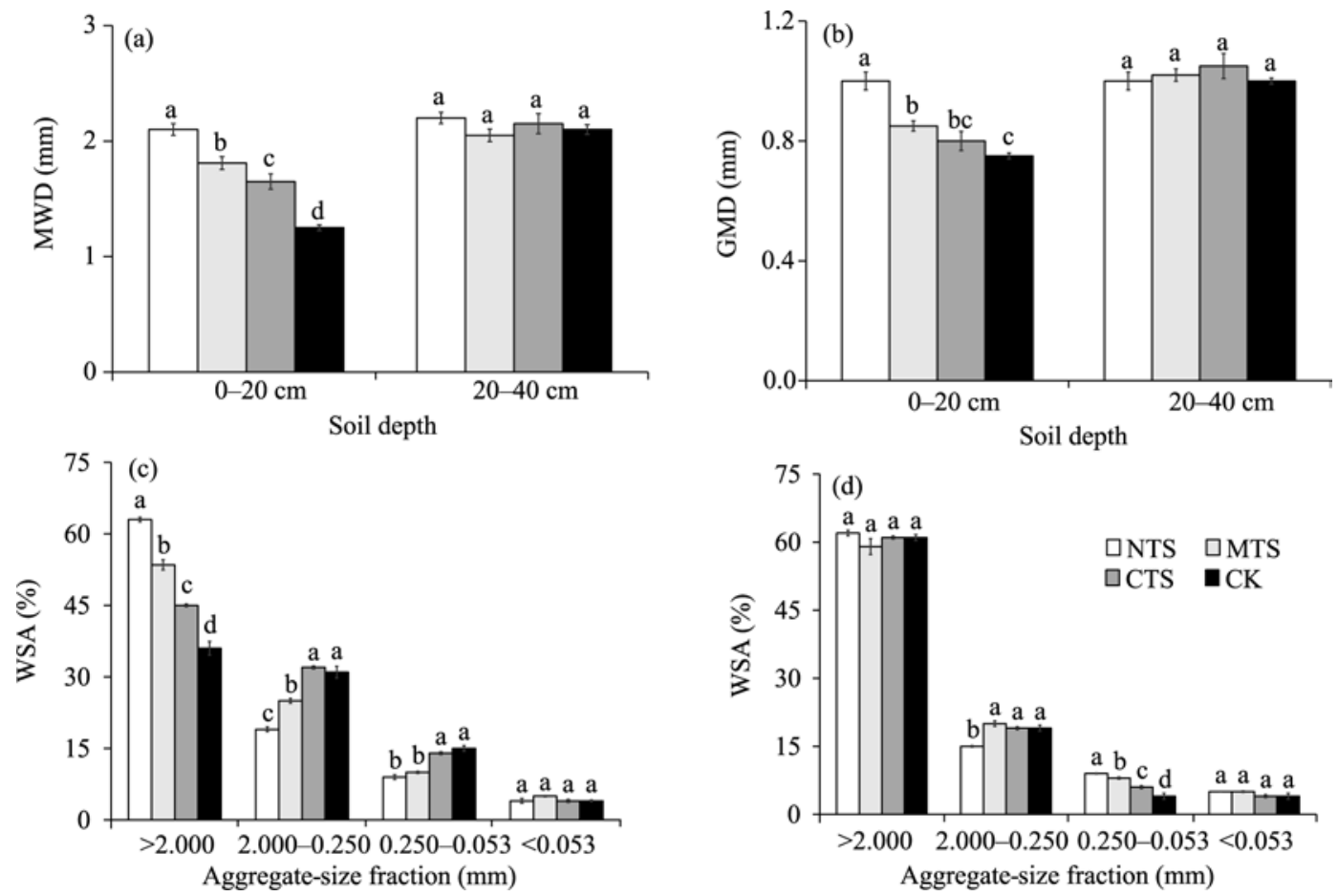

Fig. 1 Mean weight diameter (MWD, a), geometric mean diameter (GMD, b) and water stable aggregates (WSA) under different aggregate-size fractions and corn straw returning modes in the 0-20 (c) and 20-40 cm (d) soil depths. Error bars represent standard errors. Different lowercase letters within the same soil depth or aggregate-size fraction indicate significant differences at $P<0.05$ level. CK, no corn straw returned; NTS, corn straw placed on undisturbed soil surface; MTS, corn straw incorporated in the 0-10 cm soil depth; CTS, corn straw incorporated in the $0-20 \mathrm{~cm}$ soil depth.

Table 6 Pearson's correlation coefficients $(r)$ of SOC content with mean weight diameter (MWD), geometric mean diameter (GMD), and soil aggregate-size fractions in the $0-40 \mathrm{~cm}$ soil depth

\begin{tabular}{cllllll}
\hline Parameter & SOC & MWD & GMD & $>2.000 \mathrm{~mm}$ & $2.000-0.250 \mathrm{~mm}$ & $0.250-0.053 \mathrm{~mm}$ \\
\hline MWD & $0.972^{*}$ & & & & & \\
GMD & $0.979^{*}$ & 0.936 & & & & \\
$>2.000 \mathrm{~mm}$ & $0.967^{*}$ & $0.988^{*}$ & $0.961^{*}$ & & & \\
$2.000-0.250 \mathrm{~mm}$ & -0.875 & -0.854 & $-0.948^{*}$ & -0.923 & 0.940 & -0.453 \\
$0.250-0.053 \mathrm{~mm}$ & -0.861 & -0.917 & -0.891 & $-0.960^{*}$ & -0.194 & -0.238 \\
$<0.053 \mathrm{~mm}$ & -0.012 & 0.202 & -0.000 & & & \\
\hline
\end{tabular}

Note: ${ }^{*}$ means significant correlation at $P<0.05$ level (2-tailed).

$0-40 \mathrm{~cm}$ soil depth. Whereas, SOC associated with $<0.053 \mathrm{~mm}$ aggregate fraction did not differ significantly in all treatments in both soil depths (Fig. 2).

Analysis of CPC showed that $>2.000 \mathrm{~mm}$ aggregate-size fraction had the highest capacity to preserve $\mathrm{C}$, and $<0.053 \mathrm{~mm}$ aggregate-size fraction showed the least capacity in both soil depths (Fig. 3). We observed that NTS had the highest capacity to store SOC especially in $>2.000 \mathrm{~mm}$ aggregates, whereas CPC in $<0.053 \mathrm{~mm}$ aggregates did not differ significantly across all corn straw returning modes in both soil depths.

\subsection{Corn yield}

Corn yields averaged 4.65, 4.69, 4.74 and 4.63 t/hm² under NTS, MTS, CTS and CK treatments, respectively, and did not significantly differ at any period of the study. Moreover, corn yield was feebly correlated $\left(R^{2}=0.2141\right)$ with SOC content (Fig. 4). 

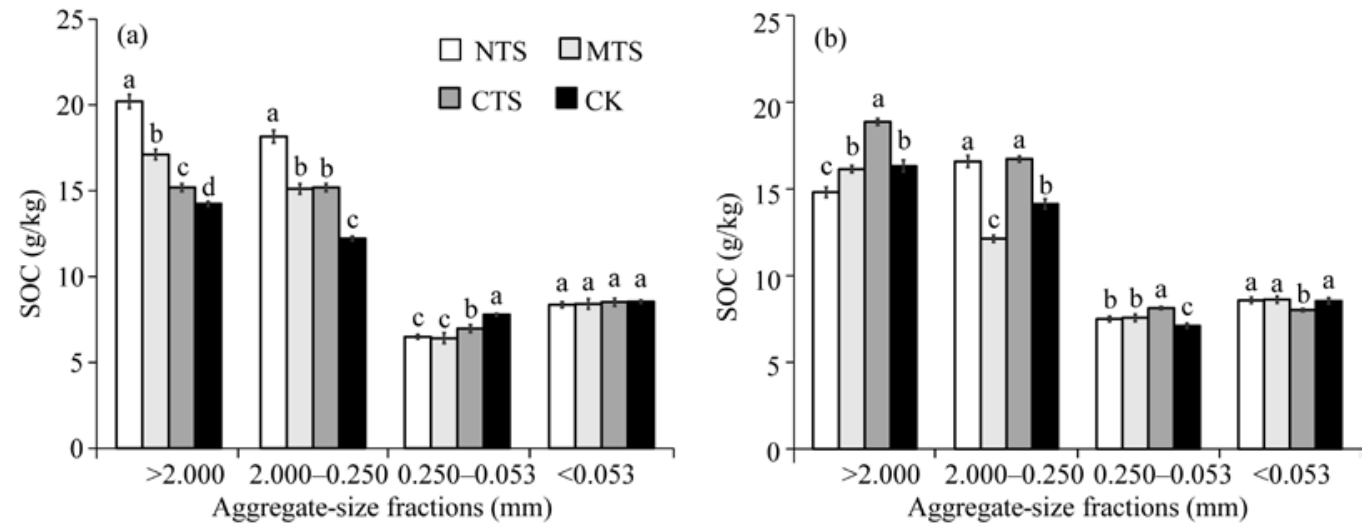

Fig. 2 Soil organic carbon (SOC) under different soil aggregate-size fractions and corn straw returning modes in the 0-20 (a) and 20-40 cm (b) soil depths. Bars represent standard errors. Different lowercase letters within the same aggregate-size fraction indicate significant differences at $P<0.05$ level. CK, no corn straw returned; NTS, corn straw placed on undisturbed soil surface; MTS, corn straw incorporated in the 0-10 cm soil depth; CTS, corn straw incorporated in the $0-20 \mathrm{~cm}$ soil depth.
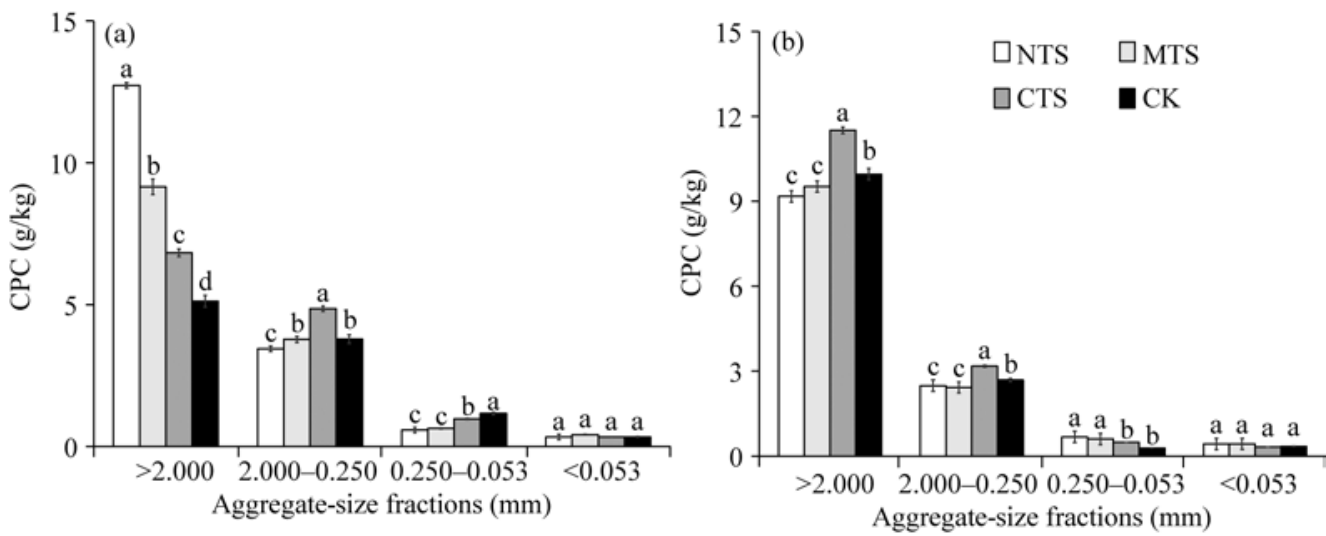

Fig. 3 Soil organic carbon preservation capacity (CPC) under different soil aggregate-size fractions and corn straw returning modes in the 0-20 (a) and 20-40 cm (b) soil depths. Different lowercase letters within the same aggregate-size fraction indicate significant differences at $P<0.05$ level. CK, no corn straw returned; NTS, corn straw placed on undisturbed soil surface; MTS, corn straw incorporated in the 0-10 cm soil depth; CTS, corn straw incorporated in the $0-20 \mathrm{~cm}$ soil depth.

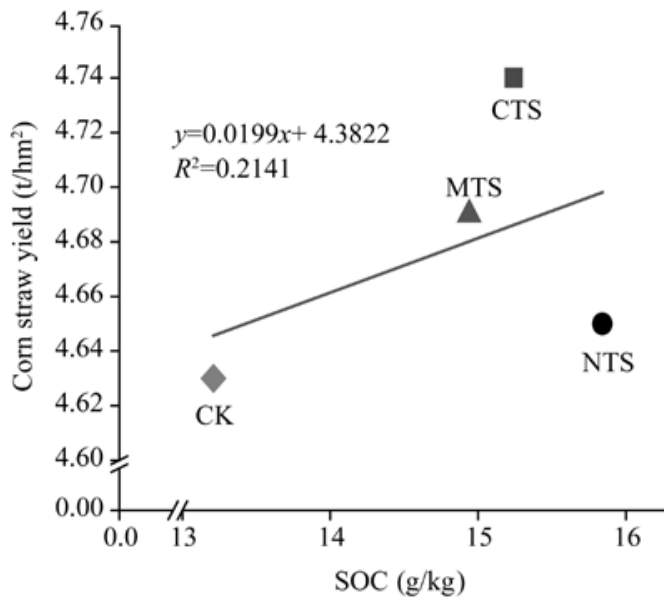

Fig. 4 Relationship between corn yield and SOC content. SOC is the average content in the 0-40 cm soil depth. CK, no corn straw returned; NTS, corn straw placed on undisturbed soil surface; MTS, corn straw incorporated in the $0-10 \mathrm{~cm}$ soil depth; CTS, corn straw incorporated in the $0-20 \mathrm{~cm}$ soil depth. 


\section{Discussion}

\subsection{Effects of corn straw returning modes on SOC content}

In this five-year study, retention of corn straw increased SOC content by $25.35 \%, 10.57 \%$ and 9.31\% under NTS, MTS and CTS treatments, respectively when compared with CK in the 0-20 cm soil depth (Table 1), and coincides with previous studies (Swanepoel et al., 2018; Pu et al., 2019; Zhang et al., 2019). As a C rich substance, application of corn straw serves as a C substrate for microbes and replenishes SOC content (Ndzelu et al., 2020), thereby contributing to the build-up of SOC. Comparing all corn straw returning modes, we found that NTS was considered to be more beneficial in increasing SOC content (Table 1). The result could be attributed to the surface retention of corn straw on undisturbed soil. Pu et al. (2019) also showed that returning crop residues on undisturbed soil significantly improved SOC content. Absence of soil disturbance decreases aggregate turnover, which in turn physically protects organic matter against microbial mineralization. In contrast, removal of corn straw and intensive tillage, for example, CK treatment breaks soil macro-aggregates, thus exposing organic matter to soil microbial mineralization (Six et al., 2002), which explains lower SOC content under CK compared with other treatments. Therefore, NTS followed by MTS is the better practice to protect SOC against mineralization in Haplic Cambisol.

\subsection{Effects of corn straw returning modes on labile soil organic carbon fractions}

Labile SOC fractions, i.e., WEOC, HWC, $\mathrm{KMnO}_{4}-\mathrm{C}$, MBC, LFOC and POC are characterized by readily decomposable organic compounds (Chen et al., 2009; Dikgwatlhe et al., 2014; Benbi et al., 2015; Chen et al., 2017; Li et al., 2018; Mi et al., 2019). Similar to other studies, we demonstrated that five years of corn straw application significantly increased the contents of labile SOC fractions compared with non-amended soils (Table 2). This indicates that soil was enriched with labile SOC fractions after corn straw application. During corn straw transformation and decomposition, Zhang et al. (2020) observed that some water-soluble substances and labile organic compounds (Chen et al., 2009) are released into the soil. Among all six labile SOC fractions measured herein, $\mathrm{KMnO}_{4}-\mathrm{C}$ and LFOC proved to be the most sensitive fractions (Table 3 ), and were significantly correlated with SOC content (Table 4), indicating that these fractions could be used as early indicators to detect the changes in SOC content in Haplic Cambisol. This coincides with previous studies, which showed that $\mathrm{LFOC}$ and $\mathrm{KMnO}_{4}-\mathrm{C}$ were the most sensitive fractions to the changes in soil management practices (Dikgwatlhe et al., 2014; Bongiorno et al., 2019).

Compared with other corn straw returning modes, NTS appeared to greatly increase the contents of each labile SOC fraction in the $0-40 \mathrm{~cm}$ soil depth (Table 2). This is because tillage incorporated corn straw into the soil under MTS and CTS treatments, which increased soil contact, thereby allowing microbes to access straw for rapid transformation and mineralization (Ndzelu et al., 2020). As a result, some portions of labile compounds are utilized by microbes as a source of energy during corn straw transformation. The increase in the contents of labile SOC fractions with soil depth under CTS (Table 2) was caused by redistribution of labile SOC fraction to deeper soil depth because of tillage. Lastly, decrease in the contents of labile SOC fractions under CK is attributed to absence of corn straw and intensive tillage, which intensified organic matter decomposition and resulted in rapid mineralization of labile SOC fractions. Bongiorno et al. (2019) drew similar observation that conventional tillage decreased labile SOC fractions. Our results indicate that amending soil with corn straw residues will increase the contents of labile SOC fractions, and NTS is more conducive in increasing these fractions.

\subsection{CPI and CMI}

Blair et al. (1994) proposed the use of CMI as a useful index to monitor the effects of soil management practices on SOC. The highest values of CPI and CMI in the 0-40 cm soil depth occurred under NTS (Table 5), suggesting that soils under NTS were better managed to increase 
SOC content.

\subsection{Effects of corn straw return modes on aggregates-size distribution}

The positive correlations of SOC with MWD, GMD and $>2.000 \mathrm{~mm}$ aggregates (Table 6), suggest that SOC content acts as the cementing agent of soil stability, as reported by Xue et al. (2019). Similar to our study, previous studies in South Africa (Sithole et al., 2019) and China (Kubar et al., 2018; Gao et al., 2019; Song et al., 2019) showed that MWD, GMD and $>2.000 \mathrm{~mm}$ aggregate distribution decreased under CK. This means that mechanical soil disturbance under CK disintegrates soil aggregates, resulting in poor soil structure. Absence of significant difference in MWD, GMD and $>2.000 \mathrm{~mm}$ aggregate-size fraction across all treatments in the $20-40 \mathrm{~cm}$ soil depth (Fig. 1), is largely ascribed to the absence of soil disturbance in this depth.

SOC content associated with macro-aggregates accounted for $63.61 \%-72.10 \%$ of total organic $\mathrm{C}$ in corn straw amended soils for both soil depths (Fig. 2). This result illustrates that macro-aggregates sequester large quantities of organic $\mathrm{C}$ after corn straw returning. Similar results were observed in previous studies (Kubar et al., 2018; Gao et al., 2019; Sithole et al., 2019; Song et al., 2019), where macro-aggregates in soils amended with crop straw residues preserved more $\mathrm{C}$ than aggregates of smaller sizes, because macro-aggregates physically protected organic matter in these aggregates against chemical and biological mineralization (Six et al., 2002). By decreasing soil aggregate turnover, NTS limited organic C accessibility by soil microbes, which in turn stimulated SOC sequestration compared with other treatments (Fig. 2). This result was confirmed by CPC analysis, where macro-aggregates exhibited higher CPC than other aggregate-size fractions (Fig. 3), and suggested the importance of macro-aggregates in C sequestration (Table 6). It was observed that incorporating corn straw residues into the soil with tillage as was the case of MTS and CTS decreased SOC associated with macro-aggregates (Fig. 2), because tillage broke down soil aggregates. These results suggest that protecting SOC in macro-aggregates from mineralization might be more important to the $\mathrm{C}$ sequestration and build-up of SOC content. The SOC associated with $<0.053 \mathrm{~mm}$ fractions did not exhibit a significant difference across all corn straw returning modes and soil depths, illustrating that $\mathrm{C}$ in these fractions was stabilized by strong organo-mineral interactions. Soil C in this form has slow turnover and is stabilized for longer periods.

\subsection{Effects of different corn straw returning modes on corn yield}

Across all corn straw returning modes, no significant difference was observed in corn yield throughout the study period, but was slightly higher in soils amended with corn straw. This is consistent with the global meta-analysis by Pittelkow et al. (2015) and a study by Si et al. (2017) in northern China, which reported no significant changes in corn yield after converting from CK to corn straw return. This means that application of corn straw will not decline corn production, but will significantly improve soil quality. Most studies suggest that long-term application of corn straw could potentially improve corn yield (Song et al., 2015), because SOC took several years or decades to build-up. This might explain no significant increase in corn yields across all treatments since our study was conducted for only five years. Oldfield et al. (2019) showed that greater corn yield is significantly correlated with a higher SOC content. Improvement in soil quality in our study could be attributed to the enhanced labile SOC fractions and soil aggregation and lowered bulk density caused by the application of corn straw.

\section{Conclusions}

A five-year study evaluating the effects of corn straw returning modes on labile SOC fractions and soil aggregate stability found that: (1) corn straw returning significantly improved SOC content and its labile fractions in the $0-40 \mathrm{~cm}$ soil depth, and of all six labile SOC fractions, LFOC and $\mathrm{KMnO}_{4}-\mathrm{C}$ were the most sensitive fractions. Therefore, they are the most representative indicators and their dynamics are the best proxy of SOC quality; (2) corn straw returning improved soil aggregate stability represented by greater mean weight diameter, 
geometric mean diameter and macro-aggregates; and (3) soil macro-aggregates preserved large quantities organic $\mathrm{C}$ than other size fractions across all corn straw returning modes. Lastly, among all corn straw returning modes, NTS and MTS were more conducive to improve contents of labile SOC fractions, soil aggregate stability and organic C associated with aggregates in the $0-40 \mathrm{~cm}$ soil depth. Therefore, farmers can adopt NTS and MTS to build-up SOC and improve soil quality without suffering yield losses during the transition period. However, future studies are needed to investigate the absence of significant improvement in corn yield after soils were amended with corn straw.

\section{Acknowledgements}

The study was supported by the National Natural Science Foundation of China (42077022) and the Key Research and Development Program of Jilin Province (20200402098NC).

\section{References}

Benbi D K, Brar K, Toor A S, et al. 2015. Sensitivity of labile soil organic carbon pools to long-term fertilizer, straw and manure management in rice-wheat system. Pedosphere, 25(4): 534-545.

Blair G J, Lefroy R D, Lisle L. 1994. Soil carbon fractions based on their degree of oxidation, and the development of a carbon management index for agricultural systems. Australian Journal of Agricultural Research, 46(7): 1459-1466.

Bongiorno G, Bünrmann E L, Oguejiofor C U, et al. 2019. Sensitivity of labile carbon fractions to tillage and organic matter management and their potential as comprehensive soil quality indicators across pedoclimatic conditions in Europe. Ecological Indicators, 99: 38-50.

Bremner J M, Mulvaney C S. 1982. Nitrogen-total. In: Page A L. Methods of Soil Analyses. Chemical and Microbiological Properties ( $2^{\text {nd }}$ ed.). Madison: Soil Scicence Society of America, 539-579.

Cambardella A A, Elliott E T. 1992. Particulate soil organic matter changes across a grassland cultivation sequence. Soil Science Society of American Journal, 56(3): 777-783.

Changtingny M H, Curtin D, Beare M H, et al. 2010. Influence of temperature on water-extractable organic matter and ammonium production in mineral soils. Soil Science Society of American Journal, 74(2): 517-524.

Chen H Q, Hou R X, Gong Y S, et al. 2009. Effects of 11 years of conservation tillage on soil organic matter fractions in wheat monoculture in Loess Plateau of China. Soil Tillage Research, 106(1): 85-94.

Chen Z H, Wang X, Liu X, et al. 2017. Changes in soil microbial community and organic carbon fractions under short-term straw return in a rice-wheat cropping system. Soil Tillage Research, 165: 121-127.

Culman S W, Snapp S S, Freeman M A, et al. 2012. Permanganate oxidizable carbon reflects a processed soil fraction that is sensitive to management. Soil Science Society of American Journal, 76: 494-504.

Dikgwatlhe S B, Kong F L, Chen Z D, et al. 2014. Tillage and residue management effects on temporal changes in soil organic carbon and fractions of a silty loam soil in the North China Plain. Soil Use and Management, 30(4): 496-506.

Elliott E T. 1986. Aggregate structure and carbon, nitrogen, and phosphorus in native and cultivated soils. Soil Science Society of America Journal, 50(3): 627-633.

Gao L L, Wang B S, Li S P, et al. 2019. Soil wet aggregate distribution and pore size distribution under different tillage systems after 16 years in the Loess Plateau of China. CATENA, 173: 38-47.

Gregorich E G, Carter M R, Angers D A, et al. 1994. Towards a minimum data set to assess soil organic matter quality in agricultural soils. Canadian Journal of Soil Science, 74: 367-385.

Kemper W D, Rosenau R C. 1986. Aggregate stability and size distribution. In: Klute A. Methods of Soil Analysis. Part 1. Physical and Mineralogical Methods. Madison: Soil Scicence Society of America, (9): 425-440.

Kubar K A, Huang L, Lu J, et al. 2018. Integrative effects of no-tillage and straw returning on soil organic carbon and water stable aggregation under rice- rape rotation. Chilean Journal of Agricultural Research, 78(2): 206-215.

Li J, Wen Y C, Li X H, et al. 2018. Soil labile organic carbon fractions and soil organic carbon stocks as affected by long-term organic and mineral fertilization regimes in the North China Plain. Soil Tillage Research, 175: 281-290.

Mi W H, Sun Y, Zhao C, et al. 2019. Soil organic carbon and its labile fractions in paddy soil as influenced by water regimes and straw management. Agricultural Water Management, 224: 105752.

Ndzelu B S, Dou S, Zhang X. 2020. Changes in soil humus composition and humic acid structural characteristics under different corn straw returning modes. Soil Research, 58 (5): 452-460. 
Okalebo J R, Gathua K W, Woomer P L. 2002. Laboratory Methods of Soil and Plant Analysis: A Working Manual (2 ${ }^{\text {nd }}$ ed.). Nairobi: TSBF Program UNESCO-ROSTA Soil Science Society of East Africa Technical Publication No. 1, 1-127.

Oldfield E E, Bradford M A, Wood S A. 2019. Global meta-analysis of the relationship between soil organic matter and crop yields. Soil, 5: 15-32.

Pittelkow C M, Linquist B A, Lundy M E, et al. 2015. When does no-till yield more? A global meta-analysis. Field Crops Research, 183: 156-168.

Pu C, Kan Z R, Liu P, et al. 2019. Residue management induced changes in soil organic carbon and total nitrogen under different tillage practices in the North China Plain. Journal of Integrative Agriculture, 18 (6): 1337-1347.

Si P F, Liu E K, He W Q, et al. 2018. Effect of no-tillage with straw mulch and conventional tillage on soil organic carbon pools in Northern China. Archives of Agronomy and Soil Science, 64(3): 398-408.

Sithole N J, Magwaza L S, Thibaud G R. 2019. Long-term impact of no-till conservation agriculture and N-fertilizer on soil aggregate stability, infiltration and distribution of C in different size fractions. Soil Tillage Research, 190: 147-156.

Six J, Conant R T, Paul E A, et al. 2002. Stabilization mechanisms of soil organic matter: Implications for C-saturation of soils. Plant and Soil, 241(2): 155-176.

Song K, Zheng X Q, Lv W G, et al. 2019. Effects of tillage and straw return on water-stable aggregates, carbon stabilization and crop yield in an estuarine alluvial soil. Scientific Reports, 9(1): 4586. doi: 10.1038/s41598-019-40908-9.

Song Z W, Gao H J, Zhu P, et al. 2015. Organic amendments increase corn yield by enhancing soil resilience to climate change. The Crop Journal, 3(2): 110-117.

Sun C Y, Liu J S, Wang Y, et al. 2012. Effects of long-term cultivation on soil organic carbon fractions and metal distribution in humic and lulvic acid in black soil, Northeast China. Soil Research, 50: 562-569.

Swanepoel C M, Rötter R P, van der Laan M, et al. 2018. The benefits of conservation agriculture on soil organic carbon and yield in southern Africa are site-specific. Soil Tillage Research, 183: 72-82.

Vance E D, Brookes P C, Jenkinson D S. 1987. An extraction method for measuring soil microbial biomass C. Soil Biology Biochemistry, 19(6): 703-707.

Xue B, Huang L, Huang Y N, et al. 2019. Effects of organic carbon and iron oxides on soil aggregate stability under different tillage systems in a rice-rape cropping system. CATENA, 177: 1-12.

Yang X Y, Ren W D, Sun B H, et al. 2012. Effects of contrasting soil management regimes on total and labile soil organic carbon fractions in a loess soil in China. Geoderma, 177-178: 49-56.

Zhang X, Dou S, Ndzelu B S, et al. 2020. Effects of different corn straw amendments on humus composition and structural characteristics of humic acid in black soil. Communications in Soil Science and Plant Analysis, 51(1): 107-117.

Zhang Y, Li X J, Gregorich E G, et al. 2019. Evaluating storage and pool size of soil organic carbon in degraded soils: Tillage effects when crop residue is returned. Soil Tillage Research, 192: 215-221. 